\title{
Ubiquitin binding by a variant Jab1/MPN domain in the essential pre-mRNA splicing factor Prp8p
}

\author{
PRIYA BELLARE, ${ }^{1}$ ALAN K. KUTACH, ${ }^{2}$ AMY K. RINES, ${ }^{1}$ CHRISTINE GUTHRIE, ${ }^{2}$ \\ and ERIK J. SONTHEIMER ${ }^{1}$ \\ ${ }^{1}$ Department of Biochemistry, Molecular Biology and Cell Biology, Northwestern University, Evanston, Illinois 60208, USA \\ ${ }^{2}$ Department of Biochemistry and Biophysics, University of California, San Francisco, San Francisco, California 94143-2200, USA
}

\begin{abstract}
The U1, U2, U4/U6, and U5 small nuclear ribonucleoproteins (snRNPs) are components of the spliceosome, which catalyzes pre-mRNA splicing. One of the largest and the most highly conserved proteins in the spliceosome is Prp8p, a component of the U5 snRNP. Despite its size and conservation, very few motifs have been identified that suggest specific biochemical functions. A variant of the Jab1/MPN domain found in a class of deubiquitinating enzymes is present near the $C$ terminus of Prp8p. Ubiquitination regulates a broad range of cellular pathways, and its functions generally require ubiquitin recognition by one or more ubiquitin-binding domains (UBDs). No precise role for ubiquitin has been defined in the pre-mRNA splicing pathway, and no known UBDs have been found within splicing proteins. Here we show that a Prp8p fragment containing the Jab1/MPN domain binds directly to ubiquitin with an affinity comparable to other known UBDs. Several mutations within this domain that compromise splicing also reduce interaction of the fragment with ubiquitin-Sepharose. Our results define a new UBD and suggest functional links between ubiquitin and the pre-mRNA splicing machinery.
\end{abstract}

Keywords: pre-mRNA splicing; U5 snRNP; PRP8; ubiquitin; Jab1/MPN domain

\section{INTRODUCTION}

Most eukaryotic genes are interrupted by introns that must be removed to generate functional mRNA. This process of premRNA splicing entails two sequential transesterification reactions that are catalyzed by the spliceosome, a multicomponent complex formed by five small nuclear RNAs (U1, U2, U4, U5, and U6) and >100 proteins (Staley and Guthrie 1998; Brow 2002; Jurica and Moore 2003). The formation of the catalytically active spliceosome involves a very large number of specific interactions that ensure fidelity and provide opportunities for regulation (Staley and Guthrie 1998; Brow 2002).

Prp8p is a large and highly conserved U5 snRNP component (Grainger and Beggs 2005) that interacts with numerous splicing factors (Whittaker et al. 1990; Achsel et al. 1998; Kuhn et al. 1999, 2002; Stevens and Abelson 1999; BenYehuda et al. 2000; Kuhn and Brow 2000; Gottschalk et al. 2001; Stevens et al. 2001; Wiesner et al. 2002) and influences spliceosome assembly (Brown and Beggs 1992) as well as premRNA splice site selection (Umen and Guthrie 1995a,b,

Reprint requests to: Erik J. Sontheimer, Department of Biochemistry, Molecular Biology and Cell Biology, Northwestern University, 2205 Tech Drive, Evanston, IL 60208, USA; e-mail: erik@northwestern.edu; fax: (847) 491-2467.

Article and publication are at http://www.rnajournal.org/cgi/doi/ $10.1261 /$ rna.2152306.
1996; Konarska 1998; Dagher and Fu 2001). Furthermore, Prp8p interacts genetically and biochemically with all three splice sites in the pre-mRNA (Teigelkamp et al. 1995a,b; Reyes et al. 1996, 1999; Collins and Guthrie 1999; Siatecka et al. 1999; Query and Konarska 2004), which suggests a critical role during catalysis. However, its exact biochemical functions have remained unclear, partly due to a paucity of well-characterized functional motifs.

Two reports have noted the presence of a recently defined Jab1/MPN domain within Prp8p (Maytal-Kivity et al. 2002; Grainger and Beggs 2005). A subset of Jab1/ MPN domains have been implicated in catalyzing the hydrolytic removal of ubiquitin (or ubiquitin-like proteins) from target proteins with the help of a coordinated zinc(II) ion (Cope et al. 2002; Maytal-Kivity et al. 2002; Verma et al. 2002; Yao and Cohen 2002; Kikuchi et al. 2003). This coordination occurs via a sequence known as the JAMM motif within some known Jab1/MPN domaincontaining enzymes (Cope et al. 2002; Verma et al. 2002; Yao and Cohen 2002). In Prp8p, however, this sequence motif is altered, raising the question of whether its Jab1/ MPN domain can coordinate zinc(II) and function as a deubiquitinating enzyme. Other such variant Jab1/MPN domains (i.e., which contain a noncanonical JAMM motif) have been reported, but their functions are not clear (Maytal-Kivity et al. 2002). 
Many steps of gene expression are regulated by post-translational events such as phosphorylation and ubiquitination, but relatively little is known about the roles of these and other protein modifications during splicing. The presence of the conserved Jab1/MPN domain in Prp8p raises the possibility that it may perform a function involving ubiquitin. Functional links between ubiquitin and splicing have been suggested (Kramer et al. 1995; Hatakeyama et al. 2001; Rappsilber et al. 2002; Ohi et al. 2003; Peng et al. 2003; Makarova et al. 2004) but not proven. For example, Prp19p is an essential splicing factor that contains a U-box domain (found in a class of E3 ubiquitin ligases) (Hatakeyama et al. 2001) and exhibits ubiquitin ligase activity in vitro (Ohi et al. 2003). Although the physiological targets of Prp19p are unknown, the prp19-1 allele harbors a mutation in the U-box domain that abolishes ubiquitin ligase activity in vitro. Other domains related to the ubiquitin pathway have also been identified in various spliceosome components (Kramer et al. 1995; Makarova et al. 2001), though their functions have not been established. Proteomic analyses have detected ubiquitinated splicing factors (Peng et al. 2003) and have also revealed the presence of ubiquitin and ubiquitin-like proteins within purified splicing complexes (Makarov et al. 2002; Rappsilber et al. 2002). These observations prompt the questions of whether ubiquitination regulates spliceosome activity and, if so, how this regulation is achieved.

Using genetic and biochemical analyses, we have investigated the role of the Prp8p variant Jab1/MPN domain. Our studies show that Prp8p exhibits ubiquitin-binding activity and that certain mutations in the domain compromise ubiquitin binding and depress U4/U5/ U6 triple-snRNP levels. We have measured the binding affinity of ubiquitin for a Jabl/MPN domain-containing Prp8p fragment and found it to be comparable to the ubiquitin affinities of known ubiquitin-binding domains (UBDs). These observations define a new UBD, establish a distinct biochemical function of Prp8p, and strengthen the likelihood that ubiquitin helps to regulate the pre-mRNA splicing pathway.

\section{RESULTS}

\section{The Jab1/MPN domain in Prp8p is essential, and its presence is required for the stable expression of Prp8p}

Prp8p's conserved Jab1/MPN domain (Maytal-Kivity et al. 2002; Grainger and Beggs 2005) resides near the $\mathrm{C}$ terminus of the protein (Fig. 1). To investigate the role of Prp8p's Jab1/MPN domain, we deleted the amino acids 2178-2310 from Prp8p in Saccharomyces cerevisiae and expressed the mutant protein (Prp8 8 Jab1/MPNp) as the sole form of Prp8p in the cell. We found that the mutant protein was unable to support growth (Fig. 2A). To investigate the expression level of the Prp8sJab1/MPNp protein, we prepared splicing extracts from cells carrying a triple HA-tagged copy of prp84jabl/mpn in addition to an untagged PRP8. Western blot analysis using antibodies against the C-terminal tag revealed that the $\triangle \mathrm{Jab} 1 / \mathrm{MPN}$ protein was poorly expressed in comparison to wild-type protein from an otherwise isogenic strain (Fig. 2B). We conclude that the presence of the Jab1/MPN domain in Prp8p is essential for growth and promotes stable protein expression.

The only known allele of PRP8 in this domain is prp8-28 (van Nues and Beggs 2001), a temperature-sensitive mutation in which a conserved Ile (I2259) is changed to an Asn (Fig. 1B). Beggs and coworkers (van Nues and Beggs 2001) have shown that this mutation abolishes a yeast two-hybrid interaction between the $\mathrm{C}$ terminus of Prp8p and the DEIH-box ATPase Brr2p, which has been implicated in the splice-

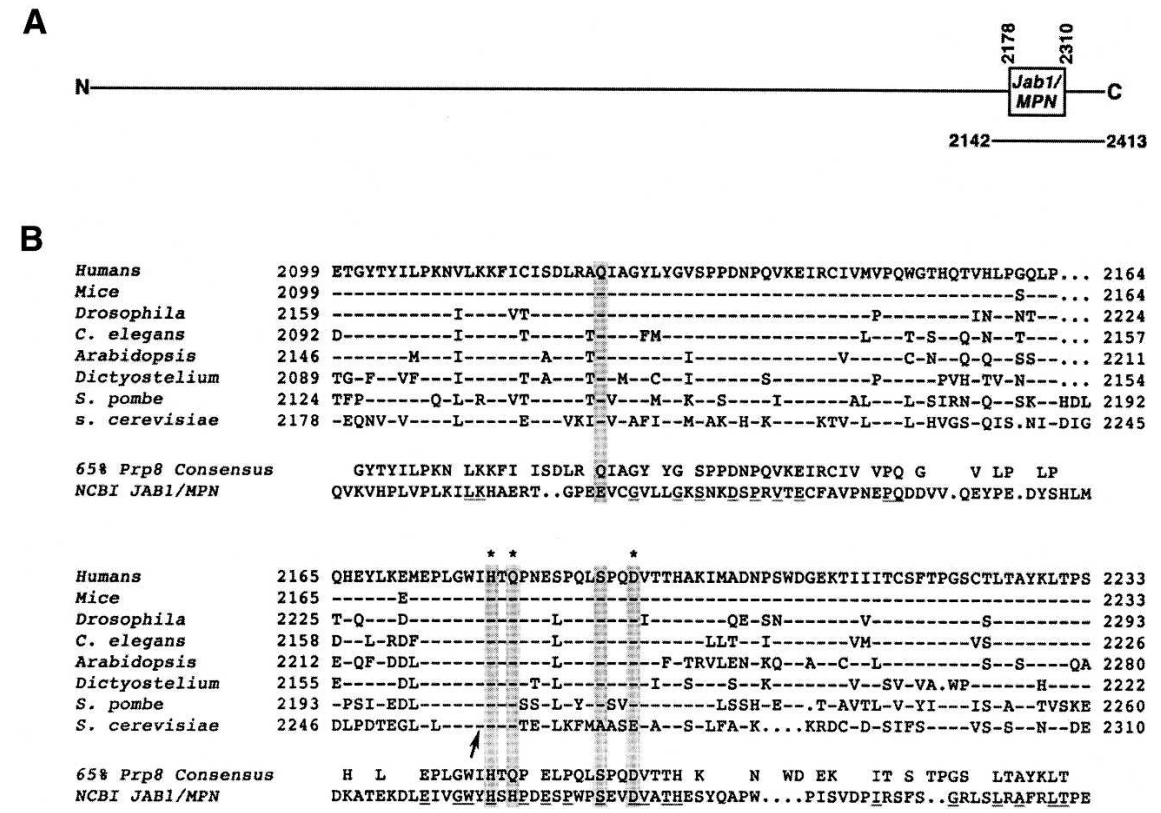

FIGURE 1. A Jab1/MPN domain near the C terminus of Prp8p. (A) The 2413-residue $S$. cerevisiae Prp8p protein carries a Jab1/MPN domain between amino acids 2178 and 2310 . A recombinant C-terminal Prp8p fragment containing the Jab1/MPN domain (see below) is depicted underneath the full-length protein. (B) Alignment of the Jab1/MPN domains of several Prp8p orthologs. Residues identical to the human sequence are represented by dashes. The positions that correspond to the JAMM motif $\left(\mathrm{E}-\mathrm{X}_{\mathrm{n}}-\mathrm{H}-\mathrm{X}-\mathrm{H}-\mathrm{X}_{7}-\mathrm{S}-\mathrm{X}_{2}-\mathrm{D}\right)$ in some other Jab1/ MPN domains (Cope et al. 2002; Maytal-Kivity et al. 2002; Verma et al. 2002; Yao and Cohen 2002 ) are shaded in gray, and those JAMM motif residues that coordinate a $\mathrm{Zn}^{2+}$ ion (Tran et al. 2003; Ambroggio et al. 2004) are denoted with asterisks. A 65\% Prp8 consensus and the representative Jab1/MPN domain from the NCBI database are aligned underneath the individual Prp8 sequences, and residues in the representative domain that match the Prp8 consensus are underlined. The site of a temperature-sensitive missense (I to $\mathrm{N}$ ) mutation in S. cerevisiae prp8-28 (van Nues and Beggs 2001) is indicated by an arrow. 
A

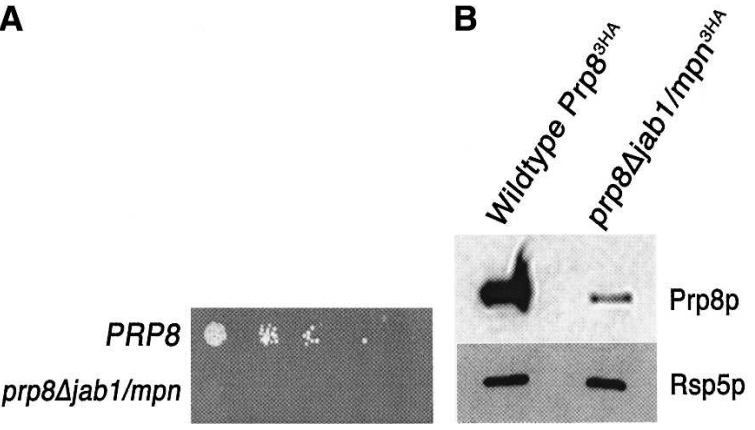

FIGURE 2. Deletion of the region containing the Prp8p Jab1/MPN domain is lethal in S. cerevisiae. (A) The Jab1/MPN domain (amino acids 2178-2310) was deleted from the PRP8 gene on a HIS3-marked plasmid (pRS313-prp8 $\Delta$ jab1/mpn-3HA). Strains harboring pRS313prp8 8 jab1/mpn-3HA as well as a wild-type PRP8 gene on a URA3marked plasmid (Kuhn et al. 1999) were grown at $25^{\circ} \mathrm{C}$ to mid-log phase in medium lacking histidine and uracil. Serial dilutions of an equal number of cells were spotted onto 5-FOA plates. Cells were grown at room temperature and analyzed after 3-4 d. (B) The Jab1/ MPN domain in Prp8p is required for stable protein expression. Splicing extracts were prepared from the strains indicated in $A$, following growth in media lacking uracil and histidine. The PRP8 allele on the HIS3-marked plasmid also contained a triple-HA tag at the $\mathrm{C}$ terminus. Equal amounts of protein were loaded on an SDS-PAGE gel and immunoblotted with an antibody against the triple-HA tag. As a loading control, the same blot was probed with $\alpha$-Rsp5p antibody.

osome's catalytic activation. This effect has also been recapitulated in vitro with a C-terminal fragment of Prp8p that contains the Jab1/MPN domain (van Nues and Beggs 2001).

\section{Residues within the noncanonical JAMM motif of Prp8p are important for efficient splicing}

Jab1/MPN domains within known deubiquitinating enzymes catalyze the removal of ubiquitin (Cope et al. 2002; Verma et al. 2002; Yao and Cohen 2002) and possess the JAMM motif (also known as the MPN+ motif [Maytal-Kivity et al. 2002]; consensus sequence $\left.\mathrm{E}-\mathrm{X}_{\mathrm{n}}-\mathrm{H}-\mathrm{X}-\mathrm{H}-\mathrm{X}_{7}-\mathrm{S}-\mathrm{X}_{2}-\mathrm{D}\right)$, which is essential for the deubiquitinating activity. The His and Asp residues in the motif coordinate a zinc(II) ion, and the Glu is thought to deprotonate a $\mathrm{Zn}^{2+}$-bound water to generate a $\mathrm{Zn}^{2+}$-hydroxide that attacks the ubiquitin-target isopeptide linkage (Tran et al. 2003; Ambroggio et al. 2004). In $S$. cerevisiae Prp8p, three of the five JAMM motif residues (Q$\left.\mathrm{X}_{\mathrm{n}}-\mathrm{H}-\mathrm{X}-\mathrm{Q}-\mathrm{X}_{7}-\mathbf{A}-\mathrm{X}_{2}-\mathrm{E}\right)$ exhibit nonconservative deviations from the canonical sequence (Fig. 1B), raising the question of whether it can coordinate the catalytically essential $\mathrm{Zn}^{2+}$ and function as a deubiquitinating enzyme. The replacement of a His residue with a Gln in Prp8p does not necessarily preclude $\mathrm{Zn}^{2+}$ coordination since the carbonyl oxygen of Gln can form an inner-sphere contact with $\mathrm{Zn}^{2+}$ (Goldberg et al. 1995; Strater et al. 1995; Lesburg et al. 1997).

To examine the importance of the noncanonical JAMM motif of Prp8p, we mutated two of the conserved residues (H2260 and Q2262; see Fig. 1B) to alanines, generating the mutant prp8-601 (Table 1). Analogous substitutions in the
Jabl/MPN domain of the essential proteasome subunit Rpn11p allow complex assembly but abolish deubiquitination activity and result in a lethal phenotype (Verma et al. 2002; Yao and Cohen 2002). When Prp8-601p was present as the sole form of Prp8p in the cell, the resulting strain exhibited wild-type growth at $25^{\circ} \mathrm{C}$ but a very mild slowgrowth phenotype at $37^{\circ} \mathrm{C}$ (Fig. 3A). Mutating four of the variant JAMM motif residues (Q2202, H2260, Q2262, and E2273) to alanines to generate the prp8-602 allele resulted in a more severe recessive slow-growth phenotype at $37^{\circ} \mathrm{C}$ (Fig. 3A). The fact that these mutants exhibit wild-type growth at $25^{\circ} \mathrm{C}$ indicates that $\mathrm{Zn}^{2+}$ coordination by this domain (if it occurs at all) is not essential. Nonetheless, the temperature-sensitive slow-growth phenotypes of the prp8601 and prp8-602 mutants indicate that the mutated residues are important for Prp8p function. Biophysical studies with an archaeal Jab1/MPN domain have shown that the JAMM residues are solvent-exposed and that Ala substitutions do not perturb the overall fold of the domain (Tran et al. 2003; Ambroggio et al. 2004). The Ala substitutions in Prp8p do not cause an obvious defect in protein expression, stability, or solubility in vivo when compared to the wildtype protein, even at the restrictive temperature (Fig. 3B). Therefore the slow-growth phenotypes of the prp8-601 and prp8-602 strains probably do not result from global effects on protein structure.

To further investigate the function of the Jab1/MPN domain in Prp8p, we generated Ala substitutions in other residues that are well conserved among Prp8 Jab1/MPN domains. Of the 18 alleles generated, three (prp8-604, prp8605, and prp8-606) were lethal (Table 1; data not shown) and three others (prp8-603, prp8-607, and prp8-608) led to a severe slow-growth phenotype at $37^{\circ} \mathrm{C}$ (Table 1 ; Fig. 3A). The remaining mutations exhibited no growth defects (Table 1; data not shown). Prp8p was poorly expressed in all of the lethal mutants at $25^{\circ} \mathrm{C}$ and in two of the three temperature-sensitive mutants (prp8-607 and prp8-608) at the nonpermissive temperature (data not shown), probably due to the structural destabilization of the protein. The prp8-603 allele, which contains Ala substitutions in V2184 and L2185 (Fig. 1B), did not affect protein expression levels in vivo at the restrictive temperature (Fig. 3B). Because the temperature-sensitive prp8601, prp8-602, prp8-603, and prp8-28 mutants were stably expressed even at the restrictive temperature, we analyzed them further to identify the source of the growth defects.

First, we examined steady-state in vivo splicing efficiencies in the mutant strains. Primer extension analysis of endogenous RNA showed that the prp8-601, prp8-602, prp8-603, and prp8-28 strains accumulated unspliced U3 pre-snoRNA in comparison to the isogenic wild-type strain (Fig. 3C). The accumulation of precursor RNA in the mutants was more pronounced at the nonpermissive temperature, with $>10$-fold accumulation of unspliced RNA in prp8-28, prp8-602, and prp8-603 compared to the isogenic wild-type strain. 
TABLE 1. S. cerevisiae strains used in this study

\begin{tabular}{lllll}
\hline Effect on growth & Strain & & Allele name & \multicolumn{1}{c}{ Source } \\
\hline NA & ANK800 & None & NA & Kuhn and Brow 2000 \\
NA & PBY2 & None & NA & This study, derivative of ANK800 \\
Lethal & PBY4 & Domain $(2178-2310)$ deletion & None & This study, derivative of ANK800 \\
& PBY5 & F2206A, I2207A, Y2208A, G2209A & prp8-604 & This study, derivative of ANK800 \\
& PBY6 & K2222A, T2223A, V2224A & prp8-605 & This study, derivative of ANK800 \\
& PBY8 & L2256A, G2257A, W2258A & prp8-606 & This study, derivative of ANK800 \\
Temperature sensitive & PBY1 & H2260A, Q2262A & prp8-601 & This study, derivative of ANK800 \\
& PBY7 & P2228A, Q2229A & prp8-608 & This study, derivative of ANK800 \\
& PBY16 & Q2202A, H2260A, Q2262A, E2273A & prp8-602 & This study, derivative of ANK800 \\
& PBY17 & I2259A & prp8-28 & This study, derivative of ANK800 \\
& PBY18 & D2198A, V2199A, K2200A & prp8-607 & This study, derivative of ANK800 \\
& PBY19 & V2184A, L2185A & prp8-603 & This study, derivative of ANK800 \\
No growth defects observed & PBY10 & E2273A, V2274A & None & This study, derivative of ANK800 \\
& PBY11 & T2276A, H2277A & None & This study, derivative of ANK800 \\
& PBY12 & M2269A, S2272A & None & This study, derivative of ANK800 \\
& PBY13 & S2278A, K2279A, L2280A & None & This study, derivative of ANK800 \\
& PBY14 & L2189A, L2190A, K2191A & None & This study, derivative of ANK800 \\
& PBY15 & E2195A, 12196A, S2197A & None & This study, derivative of ANK800 \\
& PBY20 & I2201A, Q2202A, V2203A & None & This study, derivative of ANK800 \\
& PBY21 & D2214A, H2215A, P2216A & None & This study, derivative of ANK800 \\
& PBY22 & P2186A, K2187A, N2188A & None & This study, derivative of ANK800 \\
& PBY23 & V2225A, L2226A & None & This study, derivative of ANK800 \\
& PBY24 & L2266A, K2267A, F2268A & None & This study, derivative of ANK800 \\
& PBY25 & T2263A, E2264A, E2265A & None & This study, derivative of ANK800 \\
& & & &
\end{tabular}

To investigate the cause of the in vivo splicing defect, we examined snRNP levels in splicing extracts made from all four mutant strains. Northern analysis of snRNP complexes on native polyacrylamide gels showed that levels of dissociated U5 and U4/U6 snRNPs were significantly increased in prp8-602, prp8-603, and prp8-28 compared to the isogenic wild-type strain (Fig. 4), indicating that stable triplesnRNP formation was defective in the mutants. The triplesnRNP defect in the prp8-601 mutant was more modest, consistent with its milder temperature-sensitive phenotype (Fig. 3A). Thus, particular residues within the noncanonical Jab1/MPN domain in Prp8p are important for optimal splicing in vivo and for the stable formation of the U4/ U5/U6 triple snRNP.

\section{Prp8p binds to ubiquitin, and certain residues within the Jab1/MPN domain are important for this binding}

The Prp8p Jab1/MPN domain's variations from the JAMM consensus suggest that the Prp8p domain is unlikely to harbor ubiquitin-hydrolase activity. The upstream glutamate in the canonical JAMM motif is thought to deprotonate a $\mathrm{Zn}^{2+}$ bound water in preparation for nucleophilic attack (Tran et al. 2003; Ambroggio et al. 2004). This Glu is replaced by a conserved Gln in Prp8p (Fig. 1B), and Gln is not expected to be an effective general-base catalyst. Attempts to detect deubiquitination activity in vitro with a recombinant Prp8p Cterminal fragment (see below) were unsuccessful (data not shown). Furthermore, the Prp8p Jabl/MPN domain cannot substitute for the essential and catalytically active Jab1/MPN domain (Maytal-Kivity et al. 2002; Verma et al. 2002; Yao and Cohen 2002) in the proteasome subunit Rpn11p (data not shown). Although these are negative results, they are consistent with the possibility that the Jab1/MPN domain in Prp8p does not catalyze deubiquitination as part of its normal role, despite its importance for Prp8p function.

The presence of an apparently inactive Jab1/MPN domain in Prp8p is conceptually reminiscent of the distinct ubiquitin-conjugating enzyme variant (UEV) domain, which resembles an E2 ubiquitin-conjugating enzyme in sequence and structure but lacks a critical active-site cysteine residue. Although catalytically inactive, the UEV domain functions in ubiquitin binding in multiple cellular pathways (VanDemark et al. 2001; Pornillos et al. 2002; McKenna et al. 2003; Sundquist et al. 2004; Teo et al. 2004) and provides a precedent for a pseudoenzyme domain that serves as a ubiquitin binding domain (UBD). We therefore hypothesized that the noncanonical Jab1/ MPN domain of Prp8p might function similarly as a UBD. To test this, we generated yeast lysate from cells expressing a triple HA-tagged Prp8p and passed the lysate over ubiquitin-Sepharose resin. After several washes, a fraction of the Prp8p was retained on the ubiquitin-Sepharose beads but not on Sepharose (Fig. 5A). Moreover, binding of Prp8p to the ubiquitin-Sepharose could be competed by increasing amounts of free ubiquitin (Fig. 5A), indicating that Prp8p-containing complexes could interact with ubiquitin in vitro. 
A

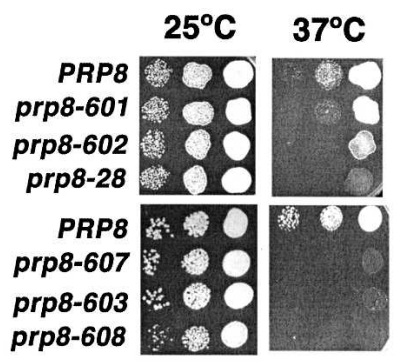

B

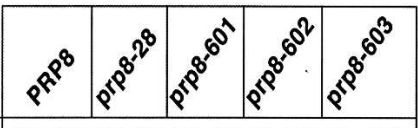

\begin{tabular}{l|llllllllll|}
${ }^{\circ} \mathrm{C}$ & 25 & 37 & 25 & 37 & 25 & 37 & 25 & 37 & 25 & 37
\end{tabular}
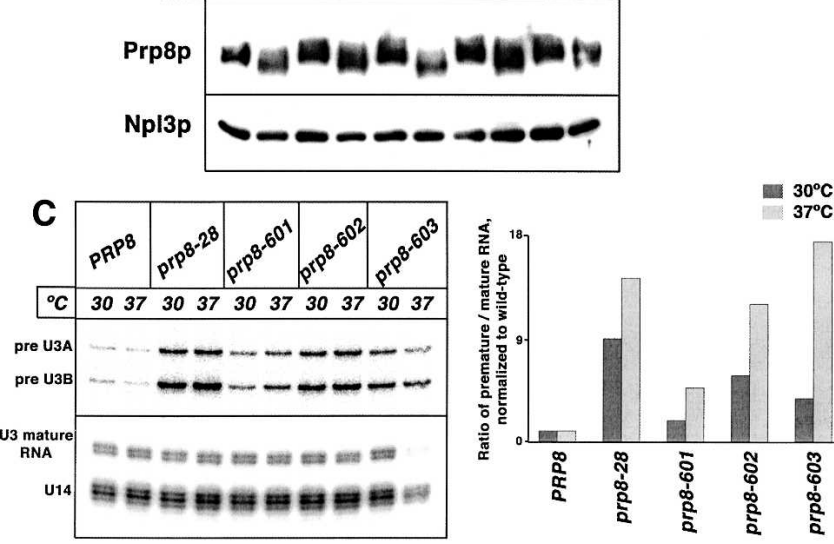

FIGURE 3. Alanine mutations in the noncanonical JAMM residues in PRP8 result in a temperature-sensitive growth phenotype. (A) The indicated strains were grown in complete media at $25^{\circ} \mathrm{C}$ up to mid-log phase, and serial dilutions of an equal number of cells were spotted onto YPD plates. Cells were grown at $25^{\circ} \mathrm{C}$ or $37^{\circ} \mathrm{C}$ and analyzed after $2 \mathrm{~d}$. (B) Alanine mutations in the variant JAMM residues of the Prp8p Jab1/MPN domain do not significantly destabilize the protein at the restrictive temperature in vivo. The indicated strains were grown at $30^{\circ} \mathrm{C}$ and then shifted to $37^{\circ} \mathrm{C}$ for $4 \mathrm{~h}$ as indicated at the top of each lane. Equivalent amounts of whole-cell extract were resolved by $10 \%$ SDS-PAGE and immunoblotted with rabbit $\alpha$-Prp8p antibodies (Collins and Guthrie 1999). As a loading control, the same blot was probed with $\alpha$-Npl3p antibodies (Siebel and Guthrie 1996). The smeariness of the Prp8p is due to its susceptibility to endogenous proteases. The mutant Prp8 proteins do not differ significantly from the wild type. (C) Mutations in the Prp8p Jab1/MPN domain reduce splicing efficiency in vivo. Total yeast RNA was prepared from the indicated strains grown as described above in $B . \mathrm{A}^{32} \mathrm{P}$-radiolabeled oligonucleotide complementary to the U3 snoRNA was hybridized to $12.5 \mu \mathrm{g}$ of total RNA and extended with M-MLV reverse transcriptase. The reaction products were resolved by denaturing gel electrophoresis and quantified with a PhosphorImager.

To test whether the observed Prp8p-ubiquitin interaction was direct or mediated by a distinct Prp8p-associated protein, we expressed a Jab1/MPN domain-containing fragment of Prp8p (amino acids 2143-2413) (Fig. 1) in bacteria and purified the recombinant protein. The purified recombinant fragment of Prp8p also bound to ubiquitinSepharose and the binding was competed by increasing amounts of free ubiquitin (Fig. 5B). This shows that the C-terminal 271 amino acids of Prp8p (including the Jab1/
MPN domain) directly bind ubiquitin in vitro. As mutating the noncanonical JAMM motif of Prp8p caused temperature sensitivity, we reasoned that the ubiquitin-binding function of these mutants might be compromised at the nonpermissive temperature. We expressed a recombinant Prp8p fragment with alanine-substituted JAMM residues (corresponding to prp8-602) as well as one with the mutations V2184A and L2185A (corresponding to prp8-603) and tested their ability to bind the ubiquitin-Sepharose resin. Ubiquitin binding by these mutants was unaffected at room temperature or $25^{\circ} \mathrm{C}$ but was significantly less than that of the wild-type fragment at the nonpermissive temperature (Fig. 5C). A quantitative estimation of the binding by fluorescent Western analysis revealed that ubiquitin binding by the prp8-602 and prp8-603 mutant fragments was approximately three- to fourfold lower than that of the wild-type fragment at $37^{\circ} \mathrm{C}$. Hence, the defective ubiquitin binding by the mutated Prp8p fragments correlates with the observed splicing defect at the nonpermissive temperature. We also tested ubiquitin binding by Prp8p fragments that contained other mutations. Specifically, the I2259A mutation (corresponding to the prp8-28 allele) within the Jab1/ MPN domain or the G2347D mutation (corresponding to

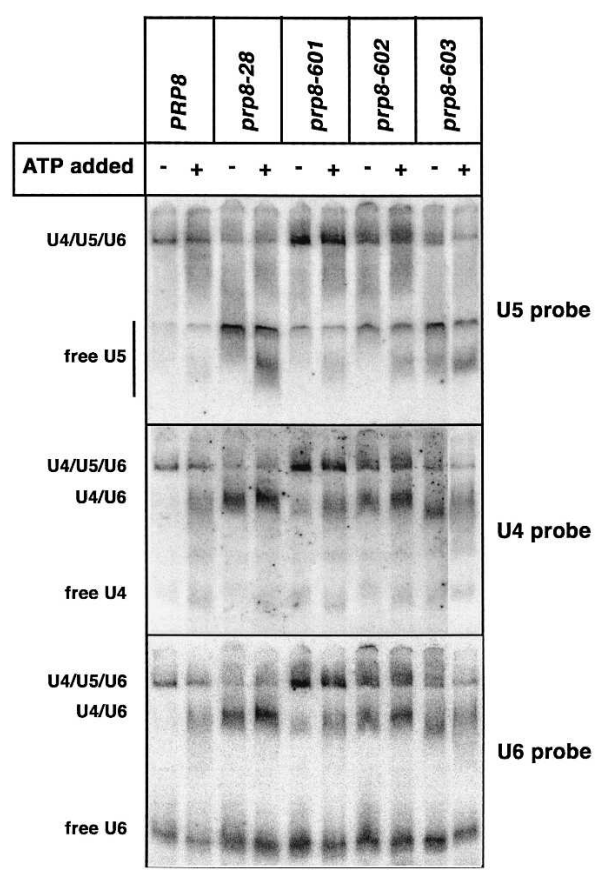

FIGURE 4. Certain mutations in the Jab1/MPN result in reduced levels of U4/U5/U6 tri-snRNP. Splicing extracts from mutant and wild-type strains were incubated at $25^{\circ} \mathrm{C}$ in the presence or the absence of $2 \mathrm{mM}$ ATP. The reactions were resolved by native polyacrylamide gel electrophoresis, transferred to Hybond-N+ membranes, and sequentially probed for U6, U5, and U4 snRNAs. The position of U4/U5/U6 tri-snRNP, U4/U6 di-snRNP, and the free snRNP complexes are indicated to the left. The rightmost lane in all three panels was loaded on the left side of the gel and then repositioned using Adobe Photoshop. All digital rendering was done to the entire file prior to cutting and pasting that lane. 
A

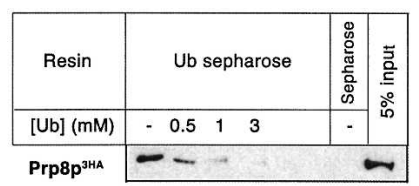

B
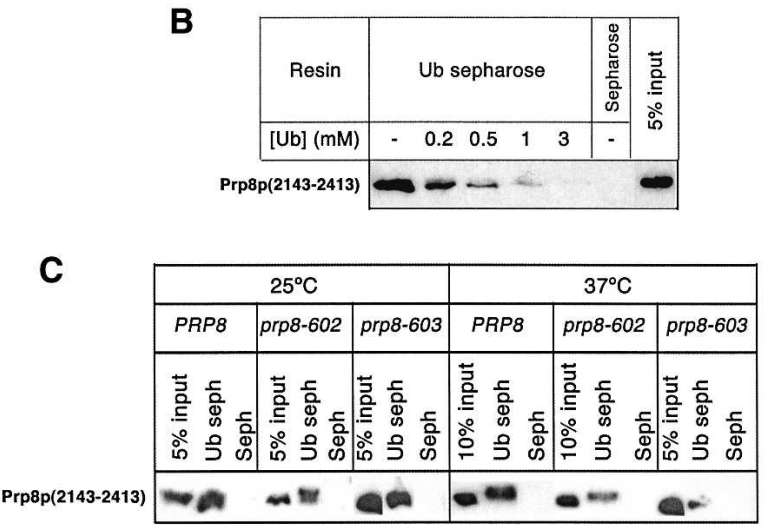

D

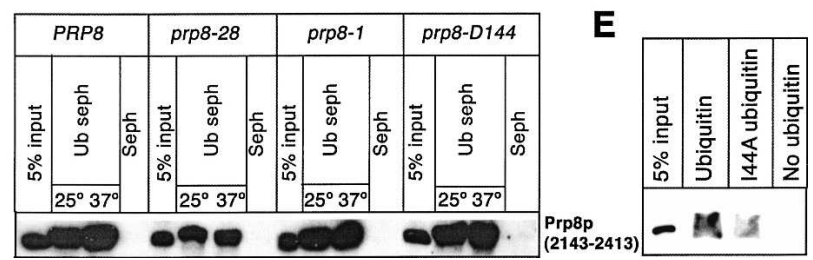

FIGURE 5. Prp8p binds ubiquitin in vitro. $(A)$ Lysate from a yeast strain expressing triple HA-tagged Prp8p was prepared and incubated with ubiquitin-Sepharose or Sepharose beads in the presence of indicated amounts of free ubiquitin. The beads were washed, and the bound material was fractionated by SDS-PAGE and immunoblotted with $\alpha$ HA antibody. For comparison, unfractionated extract corresponding to $5 \%$ of the input material was analyzed in parallel. $(B)$ Prp8p binds directly to ubiquitin in vitro. Recombinant Prp8p fragment corresponding to Cterminal residues 2143-2413 (including the Jab1/MPN domain) and Cterminal hexahistidine and HA tags was expressed and purified. The ability of this fragment to bind ubiquitin in vitro was analyzed as in $A$. $(C)$ The Jab1/MPN domain of Prp8p is important for ubiquitin binding. Untagged recombinant Prp8p fragment that contained a wild-type or mutated Jab1/MPN domain (corresponding to the prp8-602 and prp8603 alleles) was expressed in Escherichia coli. Ubiquitin binding was analyzed as in $A$, except that the binding was done at room temperature or $37^{\circ} \mathrm{C}$ and the immunoblots were probed with $\alpha$-Prp8p antisera (Collins and Guthrie 1999). (D) Mutations in Prp8p that do not affect ubiquitin binding. Untagged recombinant Prp8p fragment that contained a wild-type or mutated Jab1/MPN domain (corresponding to the prp8-1, prp8-28, and prp8-D144 alleles) was expressed in E. coli. Ubiquitin binding was analyzed as in $A$, except that the binding was done at room temperature or $37^{\circ} \mathrm{C}$ and the immunoblots were probed with $\alpha$-Prp8p antisera (Collins and Guthrie 1999). (E) An I44A mutation in ubiquitin diminishes ubiquitin binding by Prp8p fragment. Untagged recombinant Prp8p fragment that contained a wild-type Jab1/MPN domain was expressed in E. coli. Ubiquitin binding was analyzed as in $A$, except that binding was done with hexahistidine-tagged wild-type or I44A ubiquitin that was immobilized on Ni-NTA magnetic agarose resin and the immunoblots were probed with $\alpha$-Prp8p antisera (Collins and Guthrie 1999).

the prp8-1 allele) outside the Jab1/MPN domain had no significant effect on ubiquitin binding by the Prp8p frag- ment when compared to wild-type Prp8p fragment (Fig. 5D). Both prp8-1 (Hodges et al. 1995) and prp8-28 mutations have been reported to abolish interaction of Prp8 with Brr2 (van Nues and Beggs 2001) but do not disrupt the observed ubiquitin binding activity of Prp8p. In addition, a Prp8p fragment containing six different mutations, both inside and outside the domain (F2176S, I2259T, E2273D, T2296A, Q2313R, and T2364A) was found to bind ubiquitin with efficiency comparable to that of the wild-type fragment (Fig. 5D). Moreover, this allele (prp8-D144) exhibited no growth defects (data not shown). Hence the defect in ubiquitin binding was specific to the prp8-602 and prp8-603 alleles. Thus, Prp8p is able to bind to ubiquitin in a manner that is sensitive to certain mutations in its Jab1/ MPN domain. We are unable to exclude a role for the sequences adjacent to the Jab1/MPN domain in binding to ubiquitin because the flanking sequences are required for the expression of soluble recombinant protein. It remains a possibility that sequences outside of the Jab1/ MPN domain contribute to the interaction with ubiquitin.

Ubiquitin is known to engage in protein-protein interactions through an essential surface hydrophobic patch. This region contains the residue Ile44, which is important for known ubiquitin-UBD interactions, and also contains several other hydrophobic residues that contribute to binding in a manner that varies among different UBDs (Hicke et al. 2005). An I44A mutation diminishes known ubiquitin-UBD interactions and is lethal in vivo (Sloper-Mould et al. 2001; Hicke et al. 2005). We analyzed the interaction of the Prp8p fragment with I44A ubiquitin and found binding to be significantly reduced compared to wild-type ubiquitin (Fig. 5E). This result suggests that the Ile44-containing hydrophobic patch of ubiquitin contributes to Prp8p Jab1/MPN domain binding.

We measured the binding affinity between purified ubiquitin and the recombinant Prp8p fragment by surface plasmon resonance (BIAcore) experiments. Ubiquitin with a hexahistidine tag on its $\mathrm{N}$ terminus was immobilized on a nitrilotriacetic acid (NTA) sensor chip following activation by nickel chloride. Various concentrations of purified Prp8p fragment were passed over the immobilized ubiquitin to measure the binding affinity. The steady-state responses of Prp8p binding at the different concentrations (Fig. 6A) were corrected using a blank flowcell (without any immobilized ubiquitin) in parallel. These corrected responses were plotted as percent saturation as a function of Prp8p concentration, and the titration was fit to a $1: 1$ binding curve (Fig. 6B). This analysis yielded a dissociation constant of $380 \pm 70 \mu \mathrm{M}$. The measured affinity is comparable to the affinities of some known and functionally validated UBDs such as the ubiquitin interacting motif (UIM) $\left(K_{d} \sim 100-400 \mu \mathrm{M}\right)$ and the UEV domain $\left(K_{d} \sim 100-500 \mu \mathrm{M}\right)$ (Hicke et al. 2005). We were unable to analyze the binding of the mutant prp8p fragments by this method, since we could not express and purify suffi- 
A

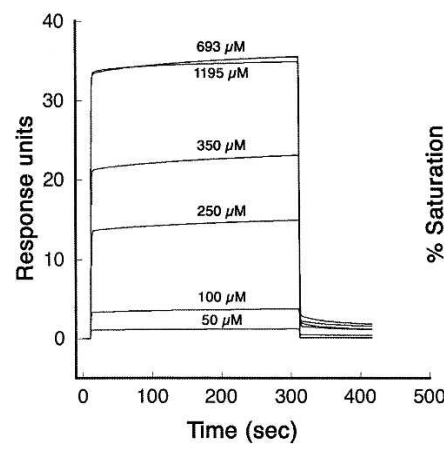

B

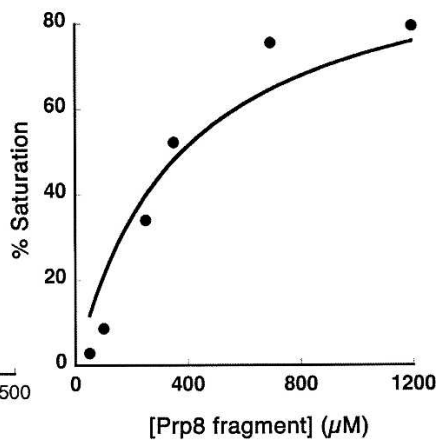

FIGURE 6. Quantitative analysis of Prp8p/ubiquitin binding by BIAcore surface plasmon resonance. $(A)$ Various concentrations of purified Prp8p fragment were injected over hexahistidine-tagged ubiquitin that was immobilized on a $\mathrm{Ni}^{2+}$-nitrilotriacetic acid ( $\mathrm{Ni}$ NTA) sensor chip. Prp8p binding was done at $4^{\circ} \mathrm{C}$ and was recorded by the instrument as "response units" that were normalized for the ubiquitin density on the chip. $(B)$ Data from $A$ were corrected for background and fit to a binding isotherm (assuming 1:1 stoichiometry) using KaleidaGraph (Synergy) software. The fit indicated an equilibrium dissociation constant $\left(K_{d}\right)$ of $380 \pm 70 \mu \mathrm{M}$.

cient quantities of soluble material. As alternative negative controls, binding assays with three unrelated proteins (carbonic anhydrase, aprotinin, and bovine serum albumin) revealed no detectable ubiquitin association (data not shown), indicating that the observed ubiquitin binding activity of Prp8p is specific.

\section{DISCUSSION}

We have shown that the presence of the conserved Jab1/ MPN domain of Prp8p is essential for viability and that temperature-sensitive mutations in this domain compromise splicing efficiency and stable U4/U5/U6 triple snRNP formation. The Prp8p Jab1/MPN domain is unlikely to harbor deubiquitination activity but instead appears to be a pseudoenzyme domain that serves a ubiquitin-binding function.

A Jab1/MPN-containing Prp8p fragment binds directly to ubiquitin with a relatively modest affinity $(380 \pm 70$ $\mu \mathrm{M})$ that is comparable to the ubiquitin affinities of other functionally validated UBDs (Hicke et al. 2005). The weak binding affinities of UBDs have been proposed to prevent promiscuous binding to free ubiquitin, which has been estimated to be present at a concentration of $10 \mu \mathrm{M}$ in mammalian cells (Haas and Bright 1987). The UBDs could still engage ubiquitinated target proteins within larger complexes, where the effective local concentration of ubiquitin would be significantly higher. In addition, UBDs with a low affinity for monoubiquitin are sometimes observed to have significantly higher affinities for polyubiquitin (Raasi et al. 2005), and the same could be true for the Prp8p Jab1/MPN domain.
Intron recognition and spliceosome activation are highly dynamic processes that rely on ordered rearrangements of spliceosome components (Staley and Guthrie 1998; Brow 2002). Multicomponent complexes such as the spliceosome can benefit from a network of low-affinity binding events like the one we observe between $\operatorname{Prp} 8 p$ and ubiquitin. A cluster of low-affinity interactions can cooperate to form a more stable binding network that can easily be modulated or reversed if required. Thus the low affinities would be compatible with the dynamic nature of the assembly process and render it more amenable to regulation.

The noncanonical nature of the JAMM motif in Prp8p suggests that zinc coordination by this domain (if it occurs) is not essential. However, mutating certain residues in the motif causes temperature-exacerbated defects in splicing, U4/U5/U6 triple snRNP levels, ubiquitin binding, and cell growth. The degree to which these phenotypes manifest as a result of disrupting interactions between the Jab1/MPN domain and ubiquitin is not clear yet. That is, the ubiquitin-binding defect is specific to $2143-2413$ fragments that harbor the prp8-602 and -603 mutations, whereas the prp828 mutation results in strong growth and splicing phenotypes but does not affect ubiquitin interaction. Thus, temperature-sensitive mutations within the Jab1/MPN domain do not necessarily result from loss of interaction with ubiquitin. Notably, we performed ubiquitin-binding analyses only on $\operatorname{prp} 8$ mutants that were stably expressed and viable. It is possible that other mutations that disrupt the ubiquitin-binding surface of the 2143-2413 fragment also cause instability or result in a lethal phenotype.

It is known that the prp8-28 mutation results in disrupted interaction with the U5 snRNP-associated RNA helicase Brr2p (van Nues and Beggs 2001). The allele-specific nature of the ubiquitin and Brr2p binding defects suggests separable functions of the region of Prp8p that contains the Jab1/MPN domain. Based on genetic analyses, Prp8p has been proposed to regulate the activities of several ATPases that promote conformational rearrangements in the splicing cycle, including catalytic activation of the spliceosome by Brr2p (Brow 2002). In addition, Prp8p is known to interact with numerous other splicing factors during spliceosome assembly (Grainger and Beggs 2005). Thus the ubiquitin-binding function for Prp8p that we have uncovered may be related to its role as a spliceosome regulator. This finding is consistent with other recent results suggesting that ubiquitination may modulate splicing. The essential splicing factor Prp19p contains a conserved U-box domain and exhibits E3 ubiquitin ligase activity in vitro (Hatakeyama et al. 2001; Ohi et al. 2003), though its targets are unknown. Another essential splicing factor, Sad1p, contains a ubiquitin C-terminal hydrolase (UCH)-like domain that lacks the usual active-site cysteine residue (Lygerou et al. 1999; Makarova et al. 2001); it is tempting to speculate that the Sad1p UCH-like domain may also bind ubiquitin. Proteomic analyses have detected 
ubiquitin in human spliceosomes (Rappsilber et al. 2002), and have also found splicing factors (Snu114p, Sad1p, and Rselp) among the population of ubiquitinated proteins from S. cerevisiae (Peng et al. 2003). Snu114p is a U5 snRNP component that is tightly associated with Prp8p (Achsel et al. 1998). Interestingly, recent analyses of SNU114 have uncovered a matrix of genetic interactions between alleles of snu114 and prp8, prp19, and sad1 (Brenner and Guthrie 2005), all of which encode proteins linked to ubiquitin. Conceivably, Prp8p may interact with a ubiquitinated splicing factor (such as Snu114p) to regulate spliceosome assembly or activity. The ubiquitin-like protein Hub1 (UBL5 in mammals) has also been implicated in splicing in fission yeast and humans (Makarov et al. 2002; Wilkinson et al. 2004), but it is not known whether the Prp8p Jab1/MPN domain can bind Hub1.

Numerous variant Jab1/MPN domains (i.e., that lack the JAMM residues) have been identified, examples of which include the Rpn8p subunit of the proteasome lid and components of the eIF3 complex (Maytal-Kivity et al. 2002; Tran et al. 2003). Biophysical studies with a JAMM-motifcontaining archael Jab1/MPN domain indicate that the $\mathrm{Zn}^{2+}$-bound and $\mathrm{Zn}^{2+}$-free forms of the protein are structurally similar (Tran et al. 2003), suggesting that the variant Jab1/MPN domains (which probably do not bind $\mathrm{Zn}^{2+}$ ) may fold similarly to the JAMM-motif-containing Jab1/ MPN domains. Although the functions of the variant Jab1/MPN domains are unclear, they are thought to promote proper interactions between subunits within their respective complexes (Maytal-Kivity et al. 2002). We have uncovered a defined activity of the noncanonical Jab1/MPN domain in Prp8p, and we suggest that other Jab1/MPN domains that lack the JAMM motif may also serve ubiquitin-binding functions. Our results not only imply a novel mode of spliceosome regulation but also add a new domain to the roster of UBDs that are critical for ubiquitin function (Hicke et al. 2005).

\section{MATERIALS AND METHODS}

\section{Strains and plasmids}

Yeast strains are listed in Table 1. The wild-type PRP8 plasmid was derived from pRS313-Prp8(SacII) (Kuhn and Brow 2000). A NotI site was introduced in this plasmid at the $C$ terminus of Prp8p by QuikChange Mutagenesis kit (Stratagene). A triple-HA epitope flanked by NotI sites was inserted to create pRS313-Prp8(SacII)3HA. Mutations were introduced in this tagged construct by QuikChange Mutagenesis (except in the case of the domain deletion) to form the mutant $\operatorname{prp} 8$ constructs. For the Jab1/MPN domain deletion, amino acids 2178-2310 were deleted by PCR-amplifying regions of DNA that flanked the domain. The amplified products contained complementary ends that were annealed in another round of PCR, resulting in a product that lacked sequences coding for the domain. This product was then extended (by PCR amplification) to include restriction sites on either end (SacII at the $5^{\prime}$ end and XmaI at the $3^{\prime}$ end) that were used to insert it into pRS313-Prp8(SacII)$3 \mathrm{HA}$ to create pRS313-prp8 $\Delta$ jab1/mpn-3HA. All mutagenized constructs were confirmed by DNA sequencing.

The prp8-601, prp8-602, and prp8-603 strains were created by shuffling wild-type and mutant $P R P 8$-bearing plasmids into the strain ANK800 (MATa snr14::TRP1 prp8A::ADE2 trp1 ura3 lys2 his3 ade2 [pRS317-U4wt] [YCp50-PRP8]) (Kuhn and Brow 2000) to replace the $U R A$-marked $P R P 8$ plasmid by 5-FOA selection. The strain harboring a copy of prp8 $8 j a b 1 / m p n$ in addition to a wildtype PRP 8 was created by transforming ANK800 with pRS313prp8 8 jabl/mpn-3HA and growing the transformants on medium that lacked histidine and uracil.

PRP8 strains for in vivo splicing analysis were made in the yeast consortium strain BY4743 (Giaever et al. 2002). The PRP8 locus was replaced with the LYS2 gene by homologous recombination and complemented by a plasmid-borne copy of $P R P 8$ marked with

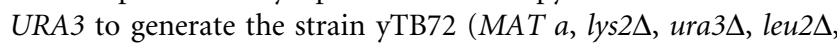
his $3 \Delta$, prp8::LYS2 pJU169). Wild-type and mutant PRP8-bearing plasmids were shuffled in to replace the URA3-marked PRP8 plasmid using 5-FOA selection. The wild-type PRP8 plasmid is pJU186, in which the XbaI/SalI fragment containing the PRP8 locus was cloned into pSE362 (CEN, ARS, HIS3). The prp8-28 mutation $(\mathrm{I} 2259 \mathrm{~N})$ was introduced by gap repair to generate pAK308. The gap-repaired region of pAK308 was sequenced to confirm the presence of a single mutation.

\section{In vivo splicing and protein analysis}

Two-hundred fifty milliliters $(250 \mathrm{~mL})$ of cultures of yeast were grown at $30^{\circ} \mathrm{C}$ in YEP $+2 \%$ glucose liquid medium to an O.D. of 1.0. One hundred milliliters $(100 \mathrm{~mL})$ of the yeast cultures were harvested for RNA and protein analyses. Fifty milliliters $(50 \mathrm{~mL})$ of the cultures were moved to flasks with $150 \mathrm{~mL}$ of fresh YEP $+2 \%$ glucose medium that had been preheated to $40^{\circ} \mathrm{C}$ and then moved to a $37^{\circ} \mathrm{C}$ incubator for $4 \mathrm{~h}$ in which time the cultures had grown to $\sim 1.0$ O.D. before harvesting for RNA and protein analyses. To harvest, the yeast cells were pelleted in a clinical centrifuge and the supernatant medium was decanted. The cells were resuspended in $1 \mathrm{~mL}$ of water (for RNA) or buffer (10 mM HEPES at pH 7.9, $100 \mathrm{mM} \mathrm{NaCl}, 5 \mathrm{mM}$ Benzamidine, $2 \mathrm{mM}$ PMSF, $5 \mathrm{mM}$ NEM, $2 \mathrm{mM}$ EDTA) (for protein) and then pelleted again. The supernatant solutions were decanted and the pellets frozen at $-80^{\circ} \mathrm{C}$.

Total yeast RNA was prepared essentially following standard procedures (Guthrie and Fink 1991) except that frozen cell pellets were resuspended with a 1:1 mixture of aqueous $50 \mathrm{mM} \mathrm{NaOAc}$, $10 \mathrm{mM}$ EDTA, and phenol: $\mathrm{CHCl}_{3}$ (5:1). The cells were extracted for $10 \mathrm{~min}$ at $65^{\circ} \mathrm{C}$ with intermittent vortexing. The purified nucleic acids were dissolved in water and adjusted to $3 \mathrm{mg} / \mathrm{mL}$ concentration as determined by UV absorbance.

Primer extension reactions were performed as described previously (Boorstein and Craig 1989). A ${ }^{32} \mathrm{P}$-labeled U3 snoRNAspecific oligonucleotide (5'-CCAAGTTGGATTCAGTGGCTC- $3^{\prime}$ ) was hybridized to $10 \mu \mathrm{g}$ of total yeast RNA and then extended with MMLV reverse transcriptase and deoxynucleotides at $45^{\circ} \mathrm{C}$. The primer extension products were resolved by $6 \%$ denaturing PAGE and analyzed using a PhosphorImager (Molecular Dynamics).

Total yeast protein was extracted from $\sim 6$ O.D. ml of culture by resuspending frozen cell pellets in SDS loading buffer $(125 \mathrm{mM}$ 
Tris at $\mathrm{pH} 6.8$, 6\% SDS, $20 \%$ glycerol, trace amounts of Bromophenol Blue, 5\% BME, $10 \mathrm{mM}$ PMSF, $2 \mathrm{mM}$ Benzamidine) to a final concentration equivalent to 20 O.D. Approximately $200 \mu \mathrm{L}$ of $0.5 \mathrm{~mm}$ glass beads were added, and the cells were homogenized using a mini Beadbeater for $3 \mathrm{~min}$, boiled for $5 \mathrm{~min}$, resolved by $10 \%$ SDS-PAGE, and then Western-blotted onto nitrocellulose.

The blots were probed for Prp8p (1:5000) and Npl3p (1:5000) rabbit sera and then with HRP conjugated goat-anti-rabbit secondary antibodies. The blots were treated with ECL reagents and exposed to film to detect the proteins.

\section{snRNP analyses}

Splicing extracts were prepared from yeast strains grown to 1.0 O.D. in $1 \mathrm{~L}$ of YEP $+2 \%$ glucose medium by the liquid nitrogen method (Umen and Guthrie 1995a). Splicing extracts $(40 \mu \mathrm{g})$ were incubated with or without $2 \mathrm{mM}$ ATP prior to being resolved by native polyacrylamide electrophoresis and transferred to Hybond-N+ membrane essentially as described previously (Raghunathan and Guthrie 1998). The blot was sequentially probed with ${ }^{32} \mathrm{P}$ phosphorylated oligos that hybridize to U6, U5, and U4 snRNAs as described previously (Noble and Guthrie 1996) and detected by phosphorimaging.

\section{Ubiquitin binding analysis}

All lysates were prepared in MES buffer (100 mM MES, $0.5 \mathrm{mM}$ magnesium chloride, $1 \mathrm{mM}$ EGTA at $\mathrm{pH}$ 6.5). Yeast lysate containing triple-HA tagged Prp8 was prepared using conventional glass bead lysis. Yeast lysate containing $10 \mathrm{mg}$ total protein or bacterial lysate containing untagged wild-type or mutant Prp8 fragment (amino acids 2143-2413) was incubated with $0.12 \mathrm{nM}$ ubiquitin Sepharose (Boston Biochem) at $4^{\circ} \mathrm{C}, 25^{\circ} \mathrm{C}$, or $37^{\circ} \mathrm{C}$ for 2 $\mathrm{h}$, following which the resin was washed three times in MES buffer. For I44A ubiquitin binding, recombinant N-terminally 6-HIS-myc tagged wild-type or I44A ubiquitin was immobilized on $200 \mu \mathrm{L}$ slurry Ni-NTA magnetic resin (Qiagen) and then incubated with bacterial lysates as explained above. The bound proteins were then analyzed by SDS PAGE and the immunoblots were probed using anti-HA antibody (1:1000) or $\alpha$-Prp8p antisera (Collins and Guthrie 1999) (1:1000).

\section{Expression and purification of recombinant Prp8p C-terminal fragment}

PCR products encoding wild-type or mutant Prp8 amino acids 2143-2413 preceded by a methionine and followed by two stop codons with or without tandem C-terminal HA and hexahistidine tags were cloned into the Gateway entry vector pDONR201 (Invitrogen). The resulting clones were sequenced to confirm that PCR had not introduced any errors. Each protein coding region was transferred from pDONR201 to the bacterial expression vector pDEST14 (Invitrogen) by recombination cloning. To express untagged fragment for SPR analysis, DNA encoding amino acids 2143-2413 of Prp8p were amplified using primers that incorporated a hexahistidine tag followed by a spacer sequence (Asp-TyrAsp-Ile-Pro-Thr-Thr) and then a Tobacco Etch Virus (TEV) protease recognition site (Glu-Asn-Leu-Tyr-Phe-Gln-Gly) at the $\mathrm{N}$ terminus. The resulting amplified product was cloned into the
pET3a vector. For the analysis of mutant versions of the Prp8p fragment, mutations were introduced by QuikChange Mutagenesis (Stratagene) and confirmed by DNA sequencing.

Vectors for the expression of Prp8p fragments were transformed into BL21(DE3)pLysS competent bacteria (Stratagene). Protein expression was induced at mid-log phase with $0.5 \mathrm{mM}$ Isopropyl-1-thio- $\beta$-D-galactopyranoside (IPTG) at $15^{\circ} \mathrm{C}$ for $16 \mathrm{~h}$. Cells were harvested and resuspended in $50 \mathrm{mM}$ sodium phosphate, 300 $\mathrm{mM}$ sodium chloride $(\mathrm{pH}$ 7.0) containing EDTA-free protease inhibitors (Roche) and lysed by sonication at $4^{\circ} \mathrm{C}$ ( 24 times for 5 sec each). Cell debris was removed by centrifugation at $20,000 \mathrm{~g}$ for $40 \mathrm{~min}$ at $4^{\circ} \mathrm{C}$ followed by filtering the supernatant using a 0.22 $\mu \mathrm{m}$ filter. Hexahistidine-tagged Prp8p fragment was purified by metal affinity chromatography using BD TALON resin (BD Biosciences Clontech) according to the manufacturer's instructions, except that the protein was eluted in $10 \mathrm{mM}$ Tris- $\mathrm{HCl}, 150 \mathrm{mM}$ Imidazole ( $\mathrm{pH}$ 8.0). For making the untagged Prp8p fragment for the SPR studies, the eluted protein was cleaved with recombinant TEV Protease (Invitrogen) for $16 \mathrm{~h}$ at $4^{\circ} \mathrm{C}$ according to the manufacturer's instructions. Following the TEV cleavage, reducing agents (EDTA and DTT) were eliminated by buffer exchange, and the protein was passed over BD TALON resin. The untagged Prp8p fragment was collected in the flowthrough and then loaded onto a HiTrap Q Sepharose resin (Amersham Pharmacia) that had been equilibrated with $10 \mathrm{mM}$ HEPES, $50 \mu \mathrm{M}$ EDTA, $0.005 \%$ Surfactant P20 (pH 7.4) (Buffer A). The protein was eluted using a linear $\mathrm{NaCl}$ gradient in Buffer $\mathrm{A}$, and elution occurred at $\sim 0.3 \mathrm{M}$ sodium chloride. For making the tagged Prp8p fragment, the protein eluted from the TALON resin was directly loaded onto the anion exchange column. This resulted in $>95 \%$ pure Prp8p fragment. The sample was desalted by buffer exchange into Buffer A in preparation for the SPR binding studies.

\section{Surface plasmon resonance binding analysis}

All components were made in Buffer A. A nitrilotriacetic acid (NTA) sensor chip (Biacore $\mathrm{AB}$ ) was activated with $\mathrm{NiCl}_{2}$ according to the manufacturer's instructions. Ubiquitin tagged at the $\mathrm{N}$ terminus with a hexahistidine tag (Boston Biochem) was immobilized on the chip by injecting $100 \mu \mathrm{L}$ of $25 \mathrm{nM}$ ubiquitin at $10 \mu \mathrm{L} / \mathrm{min}$ at $4^{\circ} \mathrm{C}$. One the four flowcells on the chip was used as a blank flowcell and was not exposed to ubiquitin. The resulting density of the immobilized ubiquitin was $R_{L}=50-100$. One hundred microliters $(100 \mu \mathrm{L})$ of varying concentrations of purified Prp8p fragment were injected at $20 \mu \mathrm{L} / \mathrm{min}$ at $4^{\circ} \mathrm{C}$ and the response values at steady state $\left(R_{\max }\right)$ were recorded. The response values in the blank flowcell were subtracted from the $R_{\max }$ values, and the percent saturation of binding sites on the chip was plotted as a function of Prp8p fragment concentration using KaleidaGraph (Synergy) software.

\section{ACKNOWLEDGMENTS}

We thank David Brow, Tamara Brenner, and Linda Hicke for strains, plasmids, and antibodies; Linda Hicke, Jonathan Staley, Sumit Prakash, and members of the Sontheimer and Guthrie laboratories for advice and discussions; and John Abelson for comments on the manuscript. We acknowledge the use of the BIAcore 2000 instrument in the Keck Biophysics Facility at North- 
western University, and we thank Mohammed Yousef at the Biophysics Core Facility of the University of Chicago for help and suggestions. C.G. is an American Cancer Society Research Professor of Molecular Genetics. This work was supported by an NIH grant (GM21119) to C.G. and an NSF CAREER Award (MCB0093003) to E.J.S.

Received July 5, 2005; accepted November 15, 2005.

\section{REFERENCES}

Achsel, T., Ahrens, K., Brahms, H., Teigelkamp, S., and Luhrmann, R. 1998. The human U5-220kD protein (hPrp8) forms a stable RNAfree complex with several U5-specific proteins, including an RNA unwindase, a homologue of ribosomal elongation factor EF-2, and a novel WD-40 protein. Mol. Cell. Biol. 18: 6756-6766.

Ambroggio, X.I., Rees, D.C., and Deshaies, R.J. 2004. JAMM: A metalloprotease-like zinc site in the proteasome and signalosome. PLoS Biol. 2: E2.

Ben-Yehuda, S., Russell, C.S., Dix, I., Beggs, J.D., and Kupiec, M. 2000. Extensive genetic interactions between PRP8 and PRP17/CDC40, two yeast genes involved in pre-mRNA splicing and cell cycle progression. Genetics 154: 61-71.

Boorstein, W.R. and Craig, E.A. 1989. Primer extension analysis of RNA. Methods Enzymol. 180: 347-369.

Brenner, T.J. and Guthrie, C. 2005. Genetic analysis reveals a role for the C-terminus of the Saccharomyces cerevisiae GTPase Snu114 during spliceosome activation. Genetics 170: 1063-1080.

Brow, D.A. 2002. Allosteric cascade of spliceosome activation. Annu. Rev. Genet. 36: 333-360.

Brown, J.D. and Beggs, J.D. 1992. Roles of PRP8 protein in the assembly of splicing complexes. EMBO J. 11: 3721-3729.

Collins, C.A. and Guthrie, C. 1999. Allele-specific genetic interactions between Prp8 and RNA active site residues suggest a function for Prp8 at the catalytic core of the spliceosome. Genes \& Dev. 13: 1970-1982.

Cope, G.A., Suh, G.S., Aravind, L., Schwarz, S.E., Zipursky, S.L., Koonin, E.V., and Deshaies, R.J. 2002. Role of predicted metalloprotease motif of Jab1/Csn5 in cleavage of Nedd8 from Cull. Science 298: 608-611.

Dagher, S.F. and Fu, X.D. 2001. Evidence for a role of Skylp-mediated phosphorylation in $3^{\prime}$ splice site recognition involving both Prp8 and Prp17/Slu4. RNA 7: 1284-1297.

Giaever, G., Chu, A.M., Ni, L., Connelly, C., Riles, L., Veronneau, S., Dow, S., Lucau-Danila, A., Anderson, K., Andre, B., et al. 2002. Functional profiling of the Saccharomyces cerevisiae genome. $\mathrm{Na}$ ture 418: 387-391.

Goldberg, J., Huang, H.B., Kwon, Y.G., Greengard, P., Nairn, A.C., and Kuriyan, J. 1995. Three-dimensional structure of the catalytic subunit of protein serine/threonine phosphatase-1. Nature 376: 745-753.

Gottschalk, A., Kastner, B., Luhrmann, R., and Fabrizio, P. 2001. The yeast U5 snRNP coisolated with the U1 snRNP has an unexpected protein composition and includes the splicing factor Aar2p. RNA 7: 1554-1565.

Grainger, R.J. and Beggs, J.D. 2005. Prp8 protein: At the heart of the spliceosome. RNA 11: 533-557.

Guthrie, C. and Fink, G.R. 1991. Guide to yeast genetics and molecular biology. Methods Enzymol. 194: 1-863.

Haas, A.L. and Bright, P.M. 1987. The dynamics of ubiquitin pools within cultured human lung fibroblasts. J. Biol. Chem. 262: 345351.

Hatakeyama, S., Yada, M., Matsumoto, M., Ishida, N., and Nakayama, K.I. 2001. U box proteins as a new family of ubiquitin-protein ligases. J. Biol. Chem. 276: 33111-33120.

Hicke, L., Schubert, H.L., and Hill, C.P. 2005. Ubiquitin-binding domains. Nat. Rev. Mol. Cell Biol. 6: 610-621.
Hodges, P.E., Jackson, S.P., Brown, J.D., and Beggs, J.D. 1995. Extraordinary sequence conservation of the PRP8 splicing factor. Yeast 11: $337-342$.

Jurica, M.S. and Moore, M.J. 2003. Pre-mRNA splicing: Awash in a sea of proteins. Mol. Cell 12: 5-14.

Kikuchi, K., Ishii, N., Asao, H., and Sugamura, K. 2003. Identification of AMSH-LP containing a Jab1/MPN domain metalloenzyme motif. Biochem. Biophys. Res. Commun. 306: 637-643.

Konarska, M.M. 1998. Recognition of the $5^{\prime}$ splice site by the spliceosome. Acta Biochim. Pol. 45: 869-881.

Kramer, A., Mulhauser, F., Wersig, C., Groning, K., and Bilbe, G. 1995. Mammalian splicing factor SF3a120 represents a new member of the SURP family of proteins and is homologous to the essential splicing factor PRP21p of Saccharomyces cerevisiae. RNA 1: 260-272.

Kuhn, A.N, and Brow, D.A. 2000. Suppressors of a cold-sensitive mutation in yeast U4 RNA define five domains in the splicing factor Prp8 that influence spliceosome activation. Genetics 155: 1667-1682.

Kuhn, A.N., Li, Z., and Brow, D.A. 1999. Splicing factor Prp8 governs U4/U6 RNA unwinding during activation of the spliceosome. Mol. Cell 3: 65-75.

Kuhn, A.N., Reichl, E.M., and Brow, D.A. 2002. Distinct domains of splicing factor Prp8 mediate different aspects of spliceosome activation. Proc. Natl. Acad. Sci. 99: 9145-9149.

Lesburg, C.A., Huang, C., Christianson, D.W., and Fierke, C.A. 1997. Histidine $\rightarrow$ carboxamide ligand substitutions in the zinc binding site of carbonic anhydrase II alter metal coordination geometry but retain catalytic activity. Biochemistry 36: 15780-15791.

Lygerou, Z., Christophides, G., and Seraphin, B. 1999. A novel genetic screen for snRNP assembly factors in yeast identifies a conserved protein, Sad1p, also required for pre-mRNA splicing. Mol. Cell. Biol. 19: 2008-2020.

Makarov, E.M., Makarova, O.V., Urlaub, H., Gentzel, M., Will, C.L., Wilm, M., and Luhrmann, R. 2002. Small nuclear ribonucleoprotein remodeling during catalytic activation of the spliceosome. Science 298: 2205-2208.

Makarova, O.V., Makarov, E.M., and Luhrmann, R. 2001. The 65 and $110 \mathrm{kDa}$ SR-related proteins of the U4/U6.U5 tri-snRNP are essential for the assembly of mature spliceosomes. EMBO J. 20: 2553-2563.

Makarova, O.V., Makarov, E.M., Urlaub, H., Will, C.L., Gentzel, M., Wilm, M., and Luhrmann, R. 2004. A subset of human 35S U5 proteins, including Prp19, function prior to catalytic step 1 of splicing. EMBO J. 23: 2381-2391.

Maytal-Kivity, V., Reis, N., Hofmann, K., and Glickman, M.H. 2002. MPN+, a putative catalytic motif found in a subset of MPN domain proteins from eukaryotes and prokaryotes, is critical for Rpn11 function. BMC Biochem. 3: 28.

McKenna, S., Moraes, T., Pastushok, L., Ptak, C., Xiao, W., Spyracopoulos, L., and Ellison, M.J. 2003. An NMR-based model of the ubiquitin-bound human ubiquitin conjugation complex Mms2. Ubc13. The structural basis for lysine 63 chain catalysis. J. Biol. Chem. 278: 13151-13158.

Noble, S.M. and Guthrie, C. 1996. Transcriptional pulse-chase analysis reveals a role for a novel snRNP-associated protein in the manufacture of spliceosomal snRNPs. EMBO J. 15: 4368-4379.

Ohi, M.D., Vander Kooi, C.W., Rosenberg, J.A., Chazin, W.J., and Gould, K.L. 2003. Structural insights into the U-box, a domain associated with multi-ubiquitination. Nat. Struct. Biol. 10: 250255.

Peng, J., Schwartz, D., Elias, J.E., Thoreen, C.C., Cheng, D., Marsischky, G., Roelofs, J., Finley, D., and Gygi, S.P. 2003. A proteomics approach to understanding protein ubiquitination. Nat. Biotechnol. 21: 921-926.

Pornillos, O., Alam, S.L., Rich, R.L., Myszka, D.G., Davis, D.R., and Sundquist, W.I. 2002. Structure and functional interactions of the Tsg101 UEV domain. EMBO J. 21: 2397-2406.

Query, C.C. and Konarska, M.M. 2004. Suppression of multiple substrate mutations by spliceosomal prp8 alleles suggests functional correlations with ribosomal ambiguity mutants. Mol. Cell 14: 343354. 
Raasi, S., Varadan, R., Fushman, D., and Pickart, C.M. 2005. Diverse polyubiquitin interaction properties of ubiquitin-associated domains. Nat. Struct. Mol. Biol. 12: 708-714.

Raghunathan, P.L. and Guthrie, C. 1998. RNA unwinding in U4/U6 snRNPs requires ATP hydrolysis and the DEIH-box splicing factor Brr2. Curr. Biol. 8: 847-855.

Rappsilber, J., Ryder, U., Lamond, A.I., and Mann, M. 2002. Largescale proteomic analysis of the human spliceosome. Genome Res. 12: $1231-1245$

Reyes, J.L., Kois, P., Konforti, B.B., and Konarska, M.M. 1996. The canonical GU dinucleotide at the $5^{\prime}$ splice site is recognized by p220 of the U5 snRNP within the spliceosome. RNA 2: 213-225.

Reyes, J.L., Gustafson, E.H., Luo, H.R., Moore, M.J., and Konarska, M.M. 1999. The C-terminal region of hPrp8 interacts with the conserved GU dinucleotide at the 5' splice site. RNA 5: 167-179.

Siatecka, M., Reyes, J.L., and Konarska, M.M. 1999. Functional interactions of Prp8 with both splice sites at the spliceosomal catalytic center. Genes \& Dev. 13: 1983-1993.

Siebel, C.W. and Guthrie, C. 1996. The essential yeast RNA binding protein Np13p is methylated. Proc. Natl. Acad. Sci. 93: 13641-13646.

Sloper-Mould, K.E., Jemc, J.C., Pickart, C.M., and Hicke, L. 2001. Distinct functional surface regions on ubiquitin. J. Biol. Chem. 276: 30483-30489.

Staley, J.P. and Guthrie, C. 1998. Mechanical devices of the spliceosome: Motors, clocks, springs, and things. Cell 92: 315-326.

Stevens, S.W. and Abelson, J. 1999. Purification of the yeast U4/U6.U5 small nuclear ribonucleoprotein particle and identification of its proteins. Proc. Natl. Acad. Sci. 96: 7226-7231.

Stevens, S.W., Barta, I., Ge, H.Y., Moore, R.E., Young, M.K., Lee, T.D., and Abelson, J. 2001. Biochemical and genetic analyses of the U5, U6, and U4/U6 x U5 small nuclear ribonucleoproteins from Saccharomyces cerevisiae. RNA 7: 1543-1553.

Strater, N., Klabunde, T., Tucker, P., Witzel, H., and Krebs, B. 1995. Crystal structure of a purple acid phosphatase containing a dinuclear Fe(III)-Zn(II) active site. Science 268: 1489-1492.

Sundquist, W.I., Schubert, H.L., Kelly, B.N., Hill, G.C., Holton, J.M., and Hill, C.P. 2004. Ubiquitin recognition by the human TSG101 protein. Mol. Cell 13: 783-789.

Teigelkamp, S., Newman, A.J., and Beggs, J.D. 1995a. Extensive interactions of PRP8 protein with the $5^{\prime}$ and $3^{\prime}$ splice sites during splicing suggest a role in stabilization of exon alignment by U5 snRNA. EMBO J. 14: 2602-2612.
Teigelkamp, S., Whittaker, E., and Beggs, J.D. 1995b. Interaction of the yeast splicing factor PRP8 with substrate RNA during both steps of splicing. Nucleic Acids Res. 23: 320-326.

Teo, H., Veprintsev, D.B., and Williams, R.L. 2004. Structural insights into endosomal sorting complex required for transport (ESCRT-I) recognition of ubiquitinated proteins. J. Biol. Chem. 279: 2868928696.

Tran, H.J., Allen, M.D., Lowe, J., and Bycroft, M. 2003. Structure of the Jab1/MPN domain and its implications for proteasome function. Biochemistry 42: 11460-11465.

Umen, J.G. and Guthrie, C. 1995a. A novel role for a U5 snRNP protein in 3' splice site selection. Genes \& Dev. 9: 855-868.

. 1995b. Prp16p, Slu7p, and Prp8p interact with the 3' splice site in two distinct stages during the second catalytic step of premRNA splicing. RNA 1: 584-597.

. 1996. Mutagenesis of the yeast gene PRP8 reveals domains governing the specificity and fidelity of $3^{\prime}$ splice site selection. Genetics 143: 723-739.

van Nues, R.W. and Beggs, J.D. 2001. Functional contacts with a range of splicing proteins suggest a central role for Brr2p in the dynamic control of the order of events in spliceosomes of Saccharomyces cerevisiae. Genetics 157: 1451-1467.

VanDemark, A.P., Hofmann, R.M., Tsui, C., Pickart, C.M., and Wolberger, C. 2001. Molecular insights into polyubiquitin chain assembly: Crystal structure of the Mms2/Ubc13 heterodimer. Cell 105: 711-720.

Verma, R., Aravind, L., Oania, R., McDonald, W.H., Yates 3rd, J.R., Koonin, E.V., and Deshaies, R.J. 2002. Role of Rpn11 metalloprotease in deubiquitination and degradation by the $26 \mathrm{~S}$ proteasome. Science 298: 611-615.

Whittaker, E., Lossky, M., and Beggs, J.D. 1990. Affinity purification of spliceosomes reveals that the precursor RNA processing protein PRP8, a protein in the U5 small nuclear ribonucleoprotein particle, is a component of yeast spliceosomes. Proc. Natl. Acad. Sci. 87: 2216-2219.

Wiesner, S., Stier, G., Sattler, M., and Macias, M.J. 2002. Solution structure and ligand recognition of the WW domain pair of the yeast splicing factor Prp40. J. Mol. Biol. 324: 807-822.

Wilkinson, C.R., Dittmar, G.A., Ohi, M.D., Uetz, P., Jones, N., and Finley, D. 2004. Ubiquitin-like protein Hub1 is required for premRNA splicing and localization of an essential splicing factor in fission yeast. Curr. Biol. 14: 2283-2288.

Yao, T. and Cohen, R.E. 2002. A cryptic protease couples deubiquitination and degradation by the proteasome. Nature 419: 403-407. 

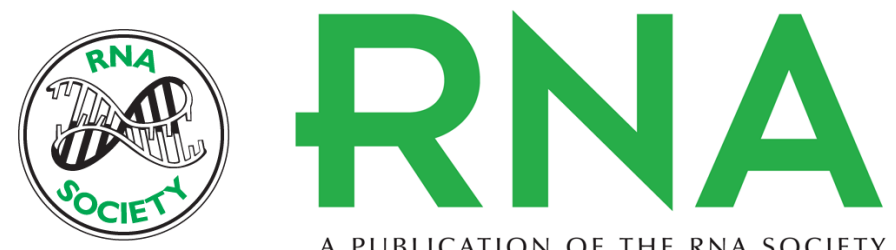

A PUBLICATION OF THE RNA SOCIETY

\section{Ubiquitin binding by a variant Jab1/MPN domain in the essential pre-mRNA splicing factor Prp8p}

PRIYA BELLARE, ALAN K. KUTACH, AMY K. RINES, et al.

RNA 2006 12: 292-302

References

This article cites 65 articles, 34 of which can be accessed free at: http://rnajournal.cshlp.org/content/12/2/292.full.html\#ref-list-1

License

Email Alerting Service right corner of the article or click here. 